\title{
Perancangan Game Physical Puzzle Rolling Kingdom
}

\author{
Mochamad Yusuf Fachroni ${ }^{1}$, Hardianto Wibowo ${ }^{2}$, Syaifuddin ${ }^{3}$ \\ Jurusan Teknik Informatika, Universitas Muhammadiyah Malang \\ e-mail: yusuf.fahroni@gmail.com¹, ardi@umm.ac.id², saif_umm@yahoo.com³
}

\begin{abstract}
Abstrak
Teknologi game saat ini mengalami perkembangan yang cukup pesat. Pemain game atau gamer kini mulai merambah di platform mobile. Salah satu kategori game yang cukup diminati adalah game dengan kategori physical puzzle. Sedangkan tema game yang diminati pada tahun 2015 adalah medieval (abad pertengahan). Game Physical Puzzle adalah sebuah genre game puzzle dimana pemain harus menggunakan hukum fisika permainan untuk menyelesaikan setiap teka-teki. Pada penelitian tugas akhir ini, peneliti mencoba membangun sebuah game physical puzzle dengan menerapkan game design document sebagai acuan perancangan desain game. Peneliti juga akan menerapkan tema medieval sebagai tema cerita game dan tema tampilan seperti user interface, latar belakang, karakter serta background music
\end{abstract}

Kata kunci: Rolling Kingdom Game, Phyiscal Puzzle, Game Design.

\begin{abstract}
Game technology is currently experiencing a fairly rapid development. Game players or gamers are now starting to spread in the mobile platform. One of the categories of games that are quite popular are games with physical puzzle category. While the theme of the game that is in demand in 2015 is medieval (medieval). Physical Puzzle Game is a puzzle game genre in which players must use the laws of physics of the game to solve every puzzle. In this final research, the researcher tries to build a game of physical puzzle by applying game design document as reference design game design. Researchers will also apply the theme of medieval as the theme of the game and the theme of the display such as user interface, background, character and background music
\end{abstract}

Keywords: Rolling Kingdom Game, Phyiscal Puzzle, Game Design. 